\title{
The impact of elephants, Loxodonta africana, on woody vegetation through selective debarking in Samburu and Buffalo Springs National Reserves, Kenya
}

\author{
Festus W. Ihwagi ${ }^{1,2}$, Fritz Vollrath ${ }^{3}$, Robert M. Chira ${ }^{2}$, Iain Douglas-Hamilton ${ }^{1}$ and \\ Geoffrey Kironchi ${ }^{2}$ \\ ${ }^{1}$ Save the Elephants, P. O. Box 54667, Nairobi, ${ }^{2}$ School of Biological Sciences, University of Nairobi, P. O. Box 30197, Nairobi, and ${ }^{3}$ Department \\ of Zoology, University of Oxford, South Parks Road, Oxford OX1 3PS, UK
}

\begin{abstract}
The impact of elephants on the woody plant community through debarking was investigated in Samburu and Buffalo Springs National Reserves, Kenya. Acacia elatior Brenan, the most abundant tree species in the riverine zone, accounted for $68 \%(\mathrm{n}=1375)$ of woody plants. A. tortilis (Forsskal) Hayne dominated plots away from the river. Debarking incidences were significantly higher for A. elatior than for other species indicating selective utilization. The riverine zone by virtue of having more trees of the preferred species, A. elatior, had the highest debarking incidences. Presence of very few saplings along the river is attributed to both elephant trampling and herbivory by other species. An estimated $38.5 \%$ and $22.5 \%$ of the riverine A. elatior and A. tortilis trees respectively, were bound to die within the next 4-5 years because of severe debarking, $\geq 75 \%$ of bark circumference. Debarking was positively correlated with stem circumference; the mediumsized trees being the worst affected by the elephants' selective debarking behaviour. Intense debarking incidences were recorded during the dry season. Through the elephants' selective debarking, the riverine habitat is bound to open up gradually, leading to considerable habitat change in the near future. Elephant impact on vegetation is less away from the river and increases with their densities.
\end{abstract}

Key words: Elephants, Samburu, selective debarking, woody plants

\section{Résumé}

L'impact des éléphants sur la communauté des plantes ligneuses, à cause de l'enlèvement des écorces, a été étudié

*Correspondence: E-mail: festus@savetheelephants.org dans les Réserves Nationales de Samburu et de Buffalo Springs, au Kenya. L'Acacia elatior Brenan, le plus abondant de la zone riveraine, comptait pour $68 \%(\mathrm{n}=1375)$ des plantes ligneuses. A. tortilis (Forsskal) Haine dominait les parcelles plus éloignées de la rivière. Les cas d'écorçage étaient significativement plus nombreux pour A. elatior que pour les autres espèces, ce qui indique une utilisation sélective. La zone riveraine, du fait qu'elle compte plus d'arbres de l'espèce préférée, A. elatior, comptait aussi le plus grand nombre de cas d'écorçage. La présence de très peu de jeunes plants le long de la rivière est attribuée au piétinement par les éléphants et à la consommation par d'autres espèces herbivores. On estime que respectivement $38,5 \%$ et $22,5 \%$ des $A$. tortilis et $A$. elatior de la zone riveraine devraient mourir dans les 4-5 années à venir, en raison d'écorçages sévères qui peuvent être de $\geq 75 \%$ de la circonférence de l'arbre. L'écorçage était positivement lié à la circonférence du tronc, les arbres de diamètre moyen étant les plus gravement affectés par le comportement sélectif des éléphants. Des cas d'écorçage intense ont été enregistrés au cours de la saison sèche. En raison de l'écorçage sélectif des éléphants, l'habitat riverain est condamné à s'ouvrir progressivement, ce qui entraînera un changement considérable dans un proche avenir. L'impact des éléphants sur la végétation est moindre lorsqu'on s'éloigne de la rivière, et il augmente en fonction de leur densité.

\section{Introduction}

The feeding habits of the African elephant (Loxodonta Africana) underlie most of the problems associated with the effects that they have on the habitat (Douglas-Hamilton, 
1972). Attention in East Africa is invariably drawn to woodland change to open grasslands in the presence of elephants (Buechner \& Dawkins, 1961). One aspect of elephant feeding behaviour that concerns wildlife managers of national parks in savanna ecosystems is their habit of stripping bark from trees (Martin, Craig \& Booth, 1990; Ruess \& Halter, 1990). Elephants use their tusks to gouge trees and then use their trunks to peel the stringy cortex off the bark (Vesey-Fitzgerald, 1973). Elephants cause vegetation change in structure and composition through their varied seasonal choice of food items that include debarking in the dry season (Pamo \& Tchamba, 2001; Holdo, 2003). When trees and shrubs are debarked by elephants, they become far more vulnerable to fires, especially during the dry season when most damage occur (Buss, 1961; Laws, 1970).

Elephants consume considerable amounts of bark and roots from felled trees to supplement their grass intake, resulting in increased impact on woody plants (Barnes, 1982). When green grass is less available during drought years, elephant are forced to increase consumption of bark earlier in the season when the bark is probably relatively the most palatable (Styles \& Skinner, 2000). The impact of elephants on woody vegetation has led to concern about possible extirpation of plant species and of animal species, the persistence of which is dependent on forest or woodland habitat (Cumming et al., 1997). The influence of elephants' large body size on foraging ecology has the potential to affect the success of some woody species and possibly lead to loss of some preferred species (O'connor, Goodman \& Clegg, 2007).

The use of different plant species by elephants falls into four broad categories in terms of how they are utilized: (i) those that are selected, (ii) those that are utilized in proportion to their occurrence, (iii) those used infrequently and (iv) those not used at all, or rejected (Page, 1995). Debarking of potentially utilizable species depends on the ease with which the bark can be separated from the stem (Douglas-Hamilton, 1972; O'connor et al., 2007). Elephants' utilization of trees entails switching to bark stripping as tree height increases (Smallie \& O'connor, 2000).

Species selection in elephants' foraging behaviour has been observed elsewhere in the past (Smallie \& O'connor, 2000; Holdo, 2003). Acacia species topped the list of preferred species in the Sahelo-Soudanian region of Congo (Pamo \& Tchamba, 2001). In the Seronera woodlands, bark damage was reported to be highest in the Acacia species component of the tree population (Ruess \& Halter,
1990). Pellew (1983) had reported that the population structure of dominant tree species, A. tortilis (Forsskal) Hayne, had changed drastically under the impacts of elephant and giraffe (Giraffa camelopardis) in a span of 7 years.

The aim of this study was to determine the patterns of the elephant utilization of woody species through debarking in Samburu and Buffalo Springs National Reserves. Over 900 individually recognized elephants use the reserves at least for some part of the year (Wittemyer, 2001). Though the reserves support the bulk of elephant population in the area (Thouless, 1995; Wittemyer, 2001), it has yet to be shown that debarking and subsequent death of some woody plants occur as a result of elephants having a distinct preference for some species. First, we sought to determine the composition of the woody plant community along the river and in the interior of the reserves. Second, we sought to determine the periods of intense debarking behaviour of elephants by ensuring that the field work spanned both a dry and a wet season. Third, we sought to determine whether elephants have a preference for any of the woody species or whether they debark randomly. More specifically, we sought to establish whether elephants exerted selective debarking pressure on Acacia elatior Brenan, and A. tortilis, as they were most abundant and extensive impact to these species could be indicative of imminent habitat change.

\section{Study site}

Samburu National Reserve (SNR) and Buffalo Springs National Reserve (BSNR) lie opposite each other at $0^{\circ} 30^{\prime} \mathrm{N}$, $37^{\circ} 30^{\prime} \mathrm{E}$, and are separated by the Ewaso Nyiro River. Both reserves have a combined area of $336 \mathrm{~km}^{2}$. The area is typically a dry savanna, which is characteristically hot and dry for most of the year with highly variable bimodal rainfall of less than $400 \mathrm{~mm}$ per annum (Jaetzold, 1983). About $90 \%$ of the mean annual rainfall occurs in the peak months of April-May and November-December (Barkham \& Rainy, 1976). Large migrant animals congregate in the reserves during the long dry season because of permanent availability of green riverine vegetation along Ewaso Nyiro River (Rainy, 1975 in Barkham \& Rainy, 1976).

To the north of the river is SNR, the surface geology of which is dominated by ancient basement complex rocks consisting of horn-blend gneisses and schists, and banded biotite gneisses (Jennings 1966 in Barkham \& Rainy, 1976). Between these are the more or less gently sloping pediments covered with recent deposits of red sand 
(Barkham \& Rainy, 1976). South of the river is BSNR, the landscape and geology of which is dominated by tertiary and more recent flows of olivine basalt giving rise to a plateau of poorly structured and excessively drained volcanic soils.

\section{Materials and methods}

The study was conducted between October 2006 and March 2007. Assessment of elephant damage to trees was carried out in ten plots along the river and five others situated away from the river, each measuring $100 \mathrm{~m} \times 100 \mathrm{~m}$ (Fig. 1). The plots away from the river were situated at least $1 \mathrm{~km}$ away from the river with the farthest being $5 \mathrm{~km}$. The plots were at least $300 \mathrm{~m}$ away from each other, and randomly distributed. Each woody plant was georeferenced with a Global Positioning System (GPS Model Garmin3.2) with an accuracy (Horizontal Position Error) of 5.5-7.5 m. A GPS enabled PDA (Model
HP h2200) with a BC-337 receiver and external AT-65 GPS antenna was used for increased accuracy where plants were very close to each other. During the first survey, all existing elephant damages to the bark were recorded. The proportion of the stem debarked at worst damage height was rated as a percentage of the circumference according to a six-point scale adapted from Walker (1976), where $0=0 \% ; \quad 1=1-25 \% ; \quad 2=26-75 \%$; $3=75 \% ; 4=76-99 \%$ and $5=100 \%$. The riverine plots formed a basis for studies on selective debarking because of the co-occurrence of more species. These were assessed for new damage fortnightly and the data compiled as monthly debarking incidences. At the end of the field study, the data were collated with the initial baseline survey data to yield total elephant damage on trees within each plot. The circumference of each plant was taken using a tape measure at the height of worst damage if a plant was debarked, or at the breast height if not debarked at all.

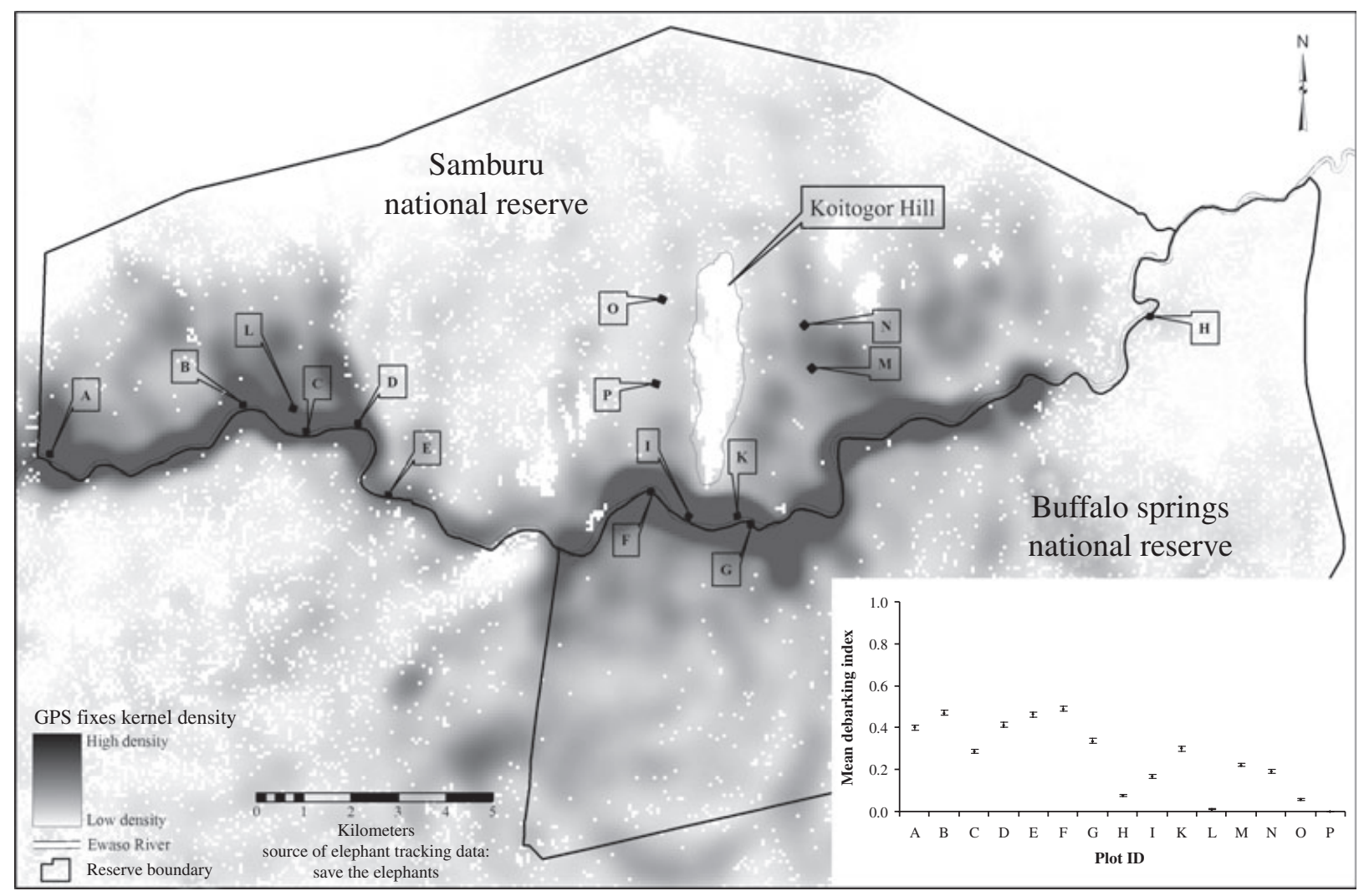

Fig 1 The location of monitoring plots (A to $\mathrm{K}$ along the river and L to $\mathrm{P}$ away from the river) and the density of hourly fixes of 48 elephants tracked in the reserves for various overlapping periods between 1998 and 2007. Inset is the overall mean debarking indices ( \pm SEM) for woody plants in each plot 
ANOVA was used to test for the differences in mean monthly debarking indices. We sought to know whether debarking intensities at the height of elephant activity in October, February and March were different between riverine and interior plots. Normal Approximation to the Mann-Whitney test was used to determine the significance of the differences.

Normality of circumferences distribution for A. tortilis and $A$. elatior was assessed graphically (Fig. 2). The statistical populations were positively skewed but normalized after $\log _{10}$ transformation. Least Square Linear Regression was used to determine dependence of debarking intensity on circumference. Two-tailed Student's t-test was used to test for the mean difference between the circumferences of riverine and interior $A$. tortilis.

To avoid bias in calculation of species preferences where trees were utilized to various degrees, the number of trees of a species within each utilization score was multiplied by a weighing factor of $0-1$. Zero corresponded to non-debarked and one to a fully ring debarked plant. The number of fully utilized trees was later calculated as the weighting factor multiplied by the frequency of individuals within the utilization class (Smallie \& O'connor, 2000). The multiplication with a weighting factor was necessary because different classes covered different ranges of debarking.

Preference ratio (PR) of the different woody species was then calculated for each species as described by Viljoen (1989);

$$
\mathrm{PR}=\mathrm{PA} / \mathrm{PU},
$$

where $\mathrm{PU}=$ percent utilization, $\mathrm{PA}=$ percent availability . $\mathrm{PA}=100 \times\left(n_{\mathrm{sp}} / N_{\mathrm{sp}}\right), \quad \mathrm{PU}=100 \times n_{\mathrm{u}} / N_{\mathrm{u}}$, where $n_{\mathrm{sp}}=$

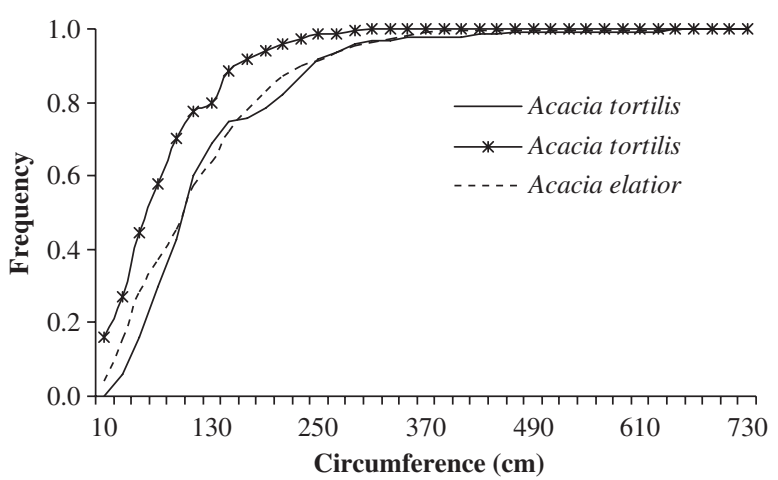

Fig 2 Cumulative relative frequency distribution of circumferences of Acacia elatior (broken line), A. tortilis trees along the river (smooth line) and $A$. tortilis away from the river (line with asterisks) number of trees of a species in a plot, $N_{\mathrm{sp}}=$ total number of all species in the plot, $n_{\mathrm{u}}=$ number of fully utilized trees of a species and $N_{\mathrm{u}}=$ number of fully utilized trees of all species in the plot.

A preferred species was defined as one that was utilized proportionately more frequently by elephants than the proportion of available trees of that species, PR $>1$ (Smallie \& O'connor, 2000). Log-likelihood ratio was used to test for significance of the difference in preference ratios.

Student's $t$-test was used to test the hypothesis of no difference between the mean values of the populations of riverine and interior A. tortilis. Shannon-Wiener diversity indices were calculated for each of the riverine plots and also for the merged plots. The diversity indices of interior plots were not calculated as these mainly comprised $A$. tortilis alone. To test for differences in recruitment of riverine and interior $A$. tortilis, circumference measurements of plants up to $50 \mathrm{~cm}$ in each zone were used. The Normal Approximation to the Mann-Whitney test was used to test for the differences in the sub-populations.

Plots were grouped into riverine and interior zones. ANOVA was used to test for the differences in debarking frequency and intensity between the zones. Debarking frequency was calculated as the proportion of injured trees to the total number of trees in the plot. The intensity was calculated as the mean of debarking indices per plot.

Data on A. tortilis were used to test for the impact of elephants on vegetation at various distances from the river and at different elephant densities. Elephant densities in and around each plot were obtained from tracking data of 48 elephants continually accumulated since 1998. Hourly GPS fixes within a circle of $564.33 \mathrm{~m}$ radius centred in each plot were extracted to provide an estimate of elephant fixes per square kilometre, a measure of elephant density. To obtain one sample representative of all riverine plots, they were merged and their mean elephant densities, debarking intensities and frequencies calculated. Because of varied circumference distributions of trees in the plots, it was necessary to subsample for a sample representative of the tree sizes targeted by elephants. Circumferences within the three heavily impacted classes $(41 \mathrm{~cm}$ to $160 \mathrm{~cm}$ ) were used for these analyses. Least square linear regression and ANOVA were used to test for elephant impact on trees at varying elephant densities and distances from the river. Pearson's correlation coefficient was used to determine the linear relationship between debarking intensities and frequencies with various elephant densities and distances from the river. 


\section{Results}

\section{Woody community structure}

A total of 1617 plants belonging to fourteen species were recorded; 1375 along the river and 242 away from the river. Thirty riverine plants were inaccessible as their circumferences could not be measured because of the presence of impenetrable Salvadora persica L. bush around them. In the riverine plots, seven of the fourteen species had very few individuals $(\mathrm{n}<10)$ (Table 1$)$. A. elatior and A. tortilis were the most abundant trees in the riparian zone, with both accounting for $85 \%$ of all woody plants recorded. A. elatior and $A$. tortilis co-occurred along the river at densities of $91 \pm 20.5$ (SE) and $22 \pm 12.3$ (SE) trees/ha respectively. The density of $A$. tortilis away from the river was $41 \pm 3.1$ (SE) trees/ha. The populations of riverine and interior $A$. tortilis were significantly different with respect to tree circumferences $\left(t_{0.05(2), 240}=6.42\right.$, $P<0.05)$. A one-tailed hypothesis, $H_{0}: \mu_{1} \geq \mu_{2}$, showed that the $A$. tortilis trees in the plots located away from the river have higher frequencies for each circumference class and remarkably more saplings (Fig. 2). The recruitment of A. tortilis in plots away from the river was higher than that in the riverine plots $\left(t_{0.05(1), \infty}=Z_{0.05(1)}=2.544\right.$, $P=0.011)$. This showed that there was higher recruitment or survival of $A$. tortilis away from the river than that within the riverine zone. Individual riverine plots exhibited low diversity indices of woody species (range $\left.0.132 \leq H^{\prime} \leq 0.517,47 \leq n \leq 243\right)$ and overall $H^{\prime}$ of $0.488(n=1375)$.

Table 1 The expected and observed proportion of trees utilized and the preference ratios of 1375 riverine woody plants of 14 species

\section{Species utilization through debarking}

The intensity of debarking varied significantly between months $\left(F_{0.05,(2) 5,60}=4.13, P=0.003\right)$. The months of November and December had the least debarking incidences. These months marked the period of short rains and elephants were conspicuously absent from the reserves, or at least along the riparian zone. There were differences in monthly mean debarking intensities $\left(\mathrm{F}_{0.05,(2) 5,60}=4.13\right.$, $P<0.05)$. October, February and March had the highest intensities and there were differences between riverine and the interior plots $\left(t_{0.05(1), \infty}=Z_{0.05(1)}=2.22, P=0.025\right)$.

The plots away from the river dominated by or entirely composed of $A$. tortilis were excluded from the analysis of preferential debarking. The 1375 riverine woody plants were considered available for utilization by elephants through debarking of which an equivalent of 431 were fully utilized, i.e. ring debarked. Individual species was not utilized in proportion to their availability, indicating selection between species $\left(G_{\text {adj }} 29.5\right.$, d.f., 13; $\left.P<0.05\right)$. High preference ratios were recorded for the few individuals of A. reficiens Wawra, A. Senegal (L.) Willd and Lepisanthes senegalensis (Juss.) Leenh, but their low sample size may have biased the outcome. A. elatior was undoubtedly the most preferred species with a preference ratio of 1.27 (Table 1).

Approximately $29.4 \%(\mathrm{n}=941)$ of all the A. elatior trees recorded both along the river and in the interior were ring debarked, while only $9.7 \% \quad(\mathrm{n}=429)$ of $A$. tortilis were ring debarked. Debarking was nevertheless more pronounced in the riparian zone where $17 \%(\mathrm{n}=226)$ of

\begin{tabular}{|c|c|c|c|c|}
\hline Species & $\begin{array}{l}\text { Number of } \\
\text { trees (n) }\end{array}$ & $\begin{array}{l}\text { Expected } \\
\text { proportion of } \\
\text { utilized trees }\end{array}$ & $\begin{array}{l}\text { Observed } \\
\text { proportion }(\mathrm{Pi}) \\
\text { of utilized trees }\end{array}$ & $\begin{array}{l}\text { Preference } \\
\text { ratio }(\mathrm{PR})\end{array}$ \\
\hline Acacia elatior & 941 & 68.44 & 86.65 & 1.27 \\
\hline A. reficiens & 4 & 0.29 & 0.46 & 1.60 \\
\hline A. senegal & 2 & 0.15 & 0.46 & 3.19 \\
\hline A. tortilis & 226 & 16.44 & 10.15 & 0.62 \\
\hline Cadaba farinossa Forssk. & 2 & 0.15 & 0.00 & 0.00 \\
\hline Combretum aculeatum Vent & 86 & 6.25 & 0.00 & 0.00 \\
\hline Cordia sinensis Lam. & 31 & 2.25 & 0.64 & 0.28 \\
\hline Gardenia volkensii K. Schum. & 6 & 0.44 & 0.00 & 0.00 \\
\hline Kigelia africana (Lam.) Benth. & 7 & 0.51 & 0.35 & 0.69 \\
\hline Lawsonia inermis L. & 23 & 1.67 & 0.00 & 0.00 \\
\hline Lepisanthes senegalensis & 8 & 0.58 & 0.70 & 1.20 \\
\hline Maerua crassifolia Forssk. & 21 & 1.53 & 0.20 & 0.13 \\
\hline Maerua oblongifolia Forssk. & 5 & 0.36 & 0.00 & 0.00 \\
\hline Prosopsis chilensis Molina & 13 & 0.95 & 0.38 & 0.40 \\
\hline
\end{tabular}

(C) 2009 The Authors. Journal compilation (C) 2009 Blackwell Publishing Ltd, Afr. J. Ecol. 
A. tortilis assessed and whose circumferences were measured had ring debarking. According to Savidge (1968), if more than half the bark has been removed, a tree has little chance of surviving for more than 4-5 years. In the riverine zone, $38.8 \%$ and $22.5 \%$ of A. elatior and A. tortilis trees respectively, had more than three quarters of their circumferences debarked at their worst damage points and consequently would not be alive in 5 years time.

Tree sizes for populations of both species had a negatively skewed distribution with a modal circumference of $40 \mathrm{~cm}$ to $60 \mathrm{~cm}$ (Figs $3 \mathrm{a}$ and $3 \mathrm{~b}$ ). There was significant dependence of debarking intensity on stem circumference for all 1579 trees whose circumferences were measured $\left(r^{2}=0.073, F_{0.5(1) 1,1579}=137.5, P<0.05\right)$. Much of debarking took place on trees with large circumferences, which were mainly A. elatior and A. tortilis. A. elatior trees were the most frequently debarked within each of the specified utilization classes (Fig. 4). The A. tortilis trees between $81 \mathrm{~cm}$ and $120 \mathrm{~cm}$ circumference had the highest debarking incidences, while these ranged between $121 \mathrm{~cm}$ and $160 \mathrm{~cm}$ for the A. elatior, the most sought after.

Debarking intensities and frequencies with respect to elephant densities and distance from water

The riparian zone had the highest elephant densities of $1855 \pm 699(\mathrm{SEM})$ fixes $\mathrm{Km}^{-2}$. Mean debarking intensities of $A$. tortilis varied with elephant densities $\left(r^{2}=0.534\right.$, $F_{0.5}$ (1) $\left.1.10=11.478, \quad P=0.007\right)$. Likewise, debarking frequencies varied with elephant densities $\left(r^{2}=0.338\right.$, $F_{0.5}$ (1)1,10 $\left.=5.112, P=0.047\right)$. There was significant difference in the mean debarking indices between riverine plots and those away from the river $\left(F_{0.5(1), 1,10}=6.354\right.$, $P=0.03)$. Both the intensity and frequency of debarking were negatively correlated to distance from water ( $r=-0.254$ and $r=-0.259$ respectively), but positively correlated to elephant density $(r=0.226$ and $r=0.192$ respectively).

\section{Discussion}

A notable aspect of the woody community structure away from the river was the absence of $A$. elatior and domination by $A$. tortilis. However, A. tortilis occurred in both regions. The age structure of $A$. tortilis trees showed that there was either a higher recruitment rate or possibly saplings survival away from the river than along the river. Differences in recruitment rates may be due to endaphic factors or other environmental factors such as herbivory and trampling. The riverine zone was heavily impacted by elephants as revealed by the tracking data. In Botswana, impalas (Aepyceros melampus) remained primarily in the heavily elephant-impacted shrub lands the whole year (Sharpe et al., 2004). Browsing by smaller herbivores, notably the impala, plays a greater role than elephants in reducing the
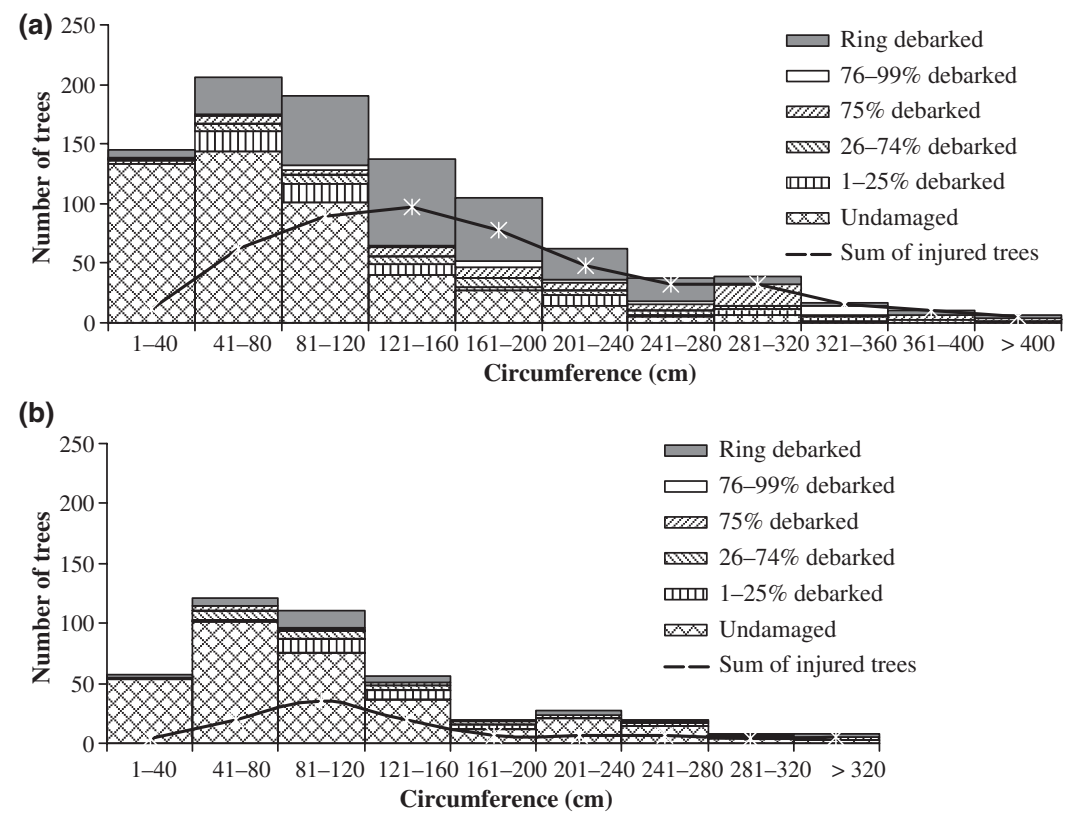

Fig 3 (a) Elephants' utilization of different sizes of Acacia elatior trees $(\mathrm{n}=955)$. (b) Elephants' utilization of different sizes of $A$. tortilis trees $(\mathrm{n}=427)$ 


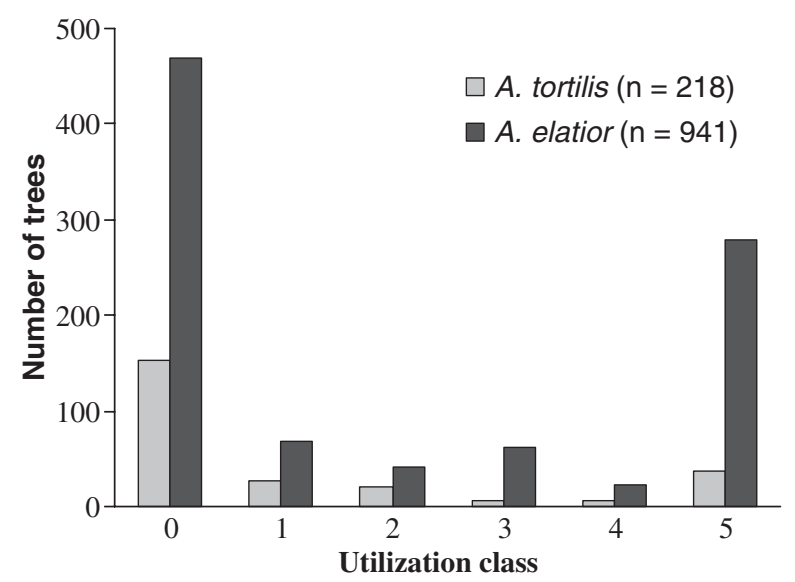

Fig 4 Frequency of utilization within each of the debarking classes for Acacia tortilis and A. elatior. Key to classes: $0=0 \%$; $1=1-25 \% ; 2=26-75 \% ; 3=75 \% ; \quad 4=76-99 \% ; \quad 5=100 \%$. $\mathrm{n}=$ number of trees assessed

survival rate of $A$. tortilis saplings (Belsky, 1984; Prins \& Van Der Jeugd, 1993). Though not tested in this study, the role of impalas cannot be overlooked as they were present in the study area. The plants occurring away from the river could have enjoyed a partial refuge from elephants and smaller water-dependent herbivores. Douglas-Hamilton (1972) working in Manyara observed that virtually no A. tortilis sapling was established under the mature trees and suggested that their growth was probably inhibited by shade or possibly by some root exudates from adults. Hence, the higher tree densities along the river could also be a factor hindering seed germination and saplings establishment. Foraging opportunities of elephant are compromised at a critical time of the year, which should force them to rely on dry land browse earlier in the season and for a greater duration (O'connor et al., 2007). A possible factor contributing to dispersal of elephants away from the riparian zone after rains is availability of alternative sources of water as temporal pools and that partly explains the low debarking incidences during the wet season. The most important spatial refuge from elephant is distance from water as elephants drink on a near daily basis which restricts foraging to within about $15 \mathrm{~km}$ from water (Conybeare, 2004).

Time of the year is an important factor in determining debarking intensity as documented in past studies that much debarking takes place towards the end of the dry season (Buss, 1961; Barnes, 1982; Viljoen, 1989). These findings are congruent with observations in this study as high incidences of debarking were recorded during the dry months of October, February and March. The low debarking incidences recorded during the wet months of November and December could be due to elephants moving away from the riparian zone after the rains when alternative food and water sources become available.

During periods of intense debarking in October, February and March, there were differences between riverine and interior plots and this is largely attributed to plant species composition and elephant densities in different parts of the reserves. Riverine plots had higher numbers of heavily debarked trees owing to the high proportion of A. elatior trees in their species assemblage. Plots away from the river experienced lower debarking intensities as these plots were dominated by the less preferred species, A. tortilis. If elephants took off roughly equal amounts of bark to fill their bite on individual trees, those with smaller circumference would acquire larger proportion of damage. Consequently, small- to medium-sized plants would have the largest percentage of their stems debarked.

Sharpe et al. (2004) found more viable seeds in the soil seed bank where elephant impact was relatively low. While the high elephant densities in the reserves exerted a direct impact on vegetation, they could also have contributed to the low recruitment rates of $A$. tortilis indirectly by reducing the quality of seed bank. The low elephant impact on vegetation away from the river is also attributed to their low preference for the dominant $A$. tortilis. Preferential debarking of $A$. elatior over $A$. tortilis has been attributed to its higher bark nutrient content (Ihwagi, 2007).

\section{Conclusion}

Debarking and associated felling of trees by elephants in the reserves increase the mortality rates of individual trees, therefore, opening up the habitat. The magnitude of the present elephant impact on the woody plant community is of concern to the reserves' management and ecologists, especially when considering the lack of regeneration of trees within the riparian zone. As the woody community serves as an important food source to elephants and other faunal species during periods of resource limitation, the selective debarking of trees potentially threatens not only the sustainability of the riparian zone but also the animal 
species that depend on the habitat type. Understanding the ultimate consequences of elephant debarking on the dynamics of the preferred species awaits a plant centred study focusing on survivorship of recruits and the progress of individual established plants after they have been debarked. This would lead to an understanding of how disturbances influence the tree community composition and structure in the particular reserves. It is also necessary to understand factors that drive elephants to debark woody vegetation through a detailed study on physiological changes in both the trees and elephants.

\section{Acknowledgements}

We are grateful to the government of Kenya and the management of Samburu and Buffalo Springs National Reserves for permission to carry out the research. We thank Christopher Leadismo and Gilbert Sabinga for their assistance during field work. We are grateful to ESRI, Charles Convis and the Society for Conservation GIS for support with GIS hardware and software.

\section{References}

Barkham, J.P. \& Rainy, M.E. (1976) The vegetation of the Samburu-Isiolo Game Reserve. E. Afr. Wildl. J. 14, 297-329.

BARNES, R.F.W. (1982) Elephant feeding behavior in Ruaha National Park, Tanzania. Afr. J. Ecol. 20, 123-136.

BELSKY, A.J. (1984) Role of small browsing mammals in preventing woodland regeneration in the Serengeti National Park, Tanzania. Afr. J. Ecol. 22, 271-279.

BUECHNER, H.K. \& DAwKINS, H.C. (1961) Vegetation change induced by elephants and fire in Murchison Fall National Park, Uganda. Ecology 42, 752-766.

Buss, I.O. (1961) Some observation on the feeding habits and the behavior of the African elephant. J. Wildl. Manage. 25, 131147.

Conybeare, A.M. (2004) Elephant impacts on vegetation and other biodiversity in the broadleaved woodlands of S-Central Africa. In: J.R. Timberlake and S.L. ChiLdes, Eds. Biodiversity of the Four Corners Area: Technical Reviews Volume Two. Biodiversity Foundation for Africa, Bulawayo/Zambezi Society, Harare. 477508.

Cumming, D.H.M., Fenton, M.B., Rautenbach, I.L., Tylor, R.D., Cumming, G.S., Cumming, M.S., Dunlop, J.M., Ford, A.G., Hovorka, M.D., Johnston, D.S., Kalcounis, M., Mahlangu, Z. \& PoRTFors, C.V.R. (1997) Elephants, woodlands and biodiversity in southern Africa. South Afr. J. Sci. 93, 231-236.

Douglas-Hamitton, I. (1972) On the Ecology and Behavior of the African elephant: The Elephant of Manyara. Thesis (PhD). University of Oxford, Oxford.
HoLdo, R.M. (2003) Woody plant damage by African elephants in relation to leaf nutrients in western Zimbabwe. J. Trop. Ecol. 19, 189-196

IhWAGI, F.W. (2007) Forage Quality and Bark Utilization by the African Elephant (Loxodonta africana) in Samburu and Buffalo Springs National Reserves, Kenya. M.Sc. Thesis, University of Nairobi, Nairobi.

JAETzoLd, R. (1983) Farm Management Handbook of Kenya. Vol. II. Ministry of Agriculture, Nairobi.

Laws, R.M. (1970) Elephants as agents of habitat and landscape change in East Africa. Oikos 21, 1-15.

Martin, R.B., Craig, G.C. \& Boоth, V.R. (1990) Elephant Management in Zimbabwe: A Review. Department of National Parks and Wildlife Management, Harare.

O'connor, T.G., Goodman, P.S. \& Clegg, B. (2007) A functional hypothesis of the threat of local extirpation of woody plant species by elephant in Africa. Biol. Conserv. 136, 329-345.

PAge, B.R. (1995) Predicting the impact of elephants on communities of woody plants. In: Elephant Management and Owners Association. Proceeds of a Workshop on the Management of the African Elephant . Aventura Resort, Warmbaths (November 1995).

Paмо, E.T. \& Tснамва, M.N. (2001) Elephants and vegetation change in the Sahelo-Soudanian region of Cameroon. J. Arid Environ. 48, 243-253.

Pellew, R.A.P. (1983) The impact of elephant, giraffe and fire upon the Acacia tortilis woodlands of the Serengeti. Afr. J. Ecol. $21,41-78$.

Prins, H.H.T. \& VAN DER Jeugd, H.P. (1993) Herbivore population crashes and woodland structure in East Africa. J. Ecol. 81, 305314.

Ruess, R.W. \& HaLter, F.L. (1990) The impact of large herbivores on the Seronera woodlands, Serengeti National Park, Tanzania. Afr. J. Ecol. 28, 259-275.

SAvidge, J.M. (1968) Elephants in the Ruaha National Park, Tanzania-management problem. E. Afr. Agric. For. J. 33, 191196.

Sharpe, C., Aarrestad, P.A., Andreassen, H.P., Dhillion, S.S., Dimakatso, T., Du Toit, J.T., Halley, D.J., Hytteborn, H., Makhabu, S., Mari, M., Marokane, W., Masunga, G., Modise, D., Moe, S.R., МојарНоко, R., Mosugelo, D., Motsumi, S., Neomahupeleng, G., Ramotadima, M., Rutina, L., Sechele, L., Sejoe, T.B., Stokke, S., Swenson, J.E., Taolo, C., Vandewalle, M. \& WegGe, P. (2004) The return of the giants: ecological effects of an increasing elephant population. Ambio 33, 276-282.

SMALLIE, J.J. \& O'ConNoR, T.G. (2000) Elephant utilization of Colophospermum mopane: possible benefits of hedging. Afr. J. Ecol. 38, 352-359.

Styles, C.V. \& SkinNer, J.D. (2000) The influence of large mammalian herbivores on growth form and utilization of mopane trees, Colophospermum mopane, in Botswana's Northern Tuli Game Reserve. Afr. J. Ecol. 38, 95-101.

Thouless, C.R. (1995) Long distance movements of elephants in northern Kenya. Afr. J. Ecol. 33, 321-334. 
Vesey-FitZgerald, D.F. (1973) Animal impact on vegetation and plant succession in Lake Manyara National Park, Tanzania. Oikos 24, 314-325.

Vitjoen, P.J. (1989) Habitat selection and preferred food plants of a desert dwelling elephant population in the northern Namib Desert, South West Africa/Namibia. Afr. J. Ecol. 27, 227-240.

WALKER, B.H. (1976) An approach to the monitoring of changes in the composition and utilization of woodland and savanna vegetation. S. Afr. J. Wildl. Res. 6, 1-32.
Wittemyer, G. (2001) The elephant population of Samburu and Buffalo Springs National Reserves, Kenya. Afr. J. Ecol. 39, 357-365.

(Manuscript accepted 9 November 2008)

doi: 10.1111/j.1365-2028.2009.01089.x 